University of Nebraska - Lincoln

DigitalCommons@University of Nebraska - Lincoln

\title{
Switchgrass Biomass Composition Traits and their Effects on its Digestion by Ruminants and Bioconversion to Ethanol
}

\author{
Kenneth P. Vogel \\ University of Nebraska-Lincoln, kvogel1@unl.edu \\ Michael D. Casler \\ USDA-ARS, michael.casler@ars.usda.gov \\ Bruce S. Dien \\ USDA-ARS, Bruce.Dien@ars.usda.gov
}

Follow this and additional works at: https://digitalcommons.unl.edu/usdaarsfacpub

Vogel, Kenneth P.; Casler, Michael D.; and Dien, Bruce S., "Switchgrass Biomass Composition Traits and their Effects on its Digestion by Ruminants and Bioconversion to Ethanol" (2017). Publications from USDA-ARS / UNL Faculty. 1966.

https://digitalcommons.unl.edu/usdaarsfacpub/1966

This Article is brought to you for free and open access by the U.S. Department of Agriculture: Agricultural Research Service, Lincoln, Nebraska at DigitalCommons@University of Nebraska - Lincoln. It has been accepted for inclusion in Publications from USDA-ARS / UNL Faculty by an authorized administrator of DigitalCommons@University of Nebraska - Lincoln. 


\title{
Switchgrass Biomass Composition Traits and their Effects on its Digestion by Ruminants and Bioconversion to Ethanol
}

\author{
Kenneth P. Vogel,^ Michael D. Casler, and Bruce S. Dien
}

\begin{abstract}
Six generations of divergent breeding in switchgrass (Panicum virgatum L.) for forage in vitro digestibility (IVDMD) resulted in significant changes in 20 biomass composition traits. Stepwise multiregression was used to determine which of the 20 composition traits had the largest significant effects on forage IVDMD and potential ethanol yield (ETOH) in a biorefinery. Switchgrass biomass samples from a field nursery containing the divergentswitchgrass populations and families were harvested after flowering, dried, ground, and analyzed for composition traits by nearinfrared reflectance analyses using previously developed near-infrared reflectance calibrations. After nonsignificant variables were eliminated, the resulting multiple regression models were highly significant $(P<0.001)$ and accounted for 95 and $96 \%$, respectively, of the total variation for both IVDMD and ETOH. Standardized partial regression coefficients were used to estimate the relative importance of each significant variable. The biomass composition factors that had the largest impact on both IVDMD and ETOH were esterified ferulates, $p$-coumarate esters, specific cell wall sugars that are involved in the linkage of cell wall lignin to hemicellulose, $\mathrm{N}$, and extracted fats. Klason lignin was not a significant variable in either regression analysis, even though it was strongly negatively correlated with both IVDMD and ETOH. The IVDMD test, which acted as a biological selection index in a longterm population breeding program, impacted an array of switchgrass biomass composition traits whose relative effects on both IVDMD and ETOH had not been previously quantified.
\end{abstract}

K.P. Vogel (retired), USDA-ARS, Grain, Forage, and Bioenergy Research Unit, 251 Filey Hall, Dep. of Agronomy and Horticulture, Univ. of Nebraska-Lincoln, Lincoln, NE 68583-0937; M.D. Casler, USDA-ARS, US Dairy Forage Research Center, 1925 W. Linden Dr., Madison, WI 53706-1108; B.S. Dien, USDA-ARS, Fermentation Biotechnology Bioenergy Research Unit, National Center for Agricultural Utilization Research, 1815 N. University St., Peoria, IL 61604. Mention of trade names or commercial products in this publication is solely to provide specific information and does not imply recommendations or endorsement by the USDA. The USDA is an equal opportunity employer. Received 25 July 2016. Accepted 15 Sept. 2016. ^Corresponding author (vogelkp61@neb.rr.com, kvogel1@unl.edu). Assigned to Associate Editor Steve Larson.

Abbreviations: ETOH, ethanol yield from biomass saccrification and fermentation; IVDMD, in vitro dry matter digestibility; NIRS, nearinfrared reflectance spectrometry; see Table 1 for an extensive listing of abbreviations for biomass composition and conversion traits.

$\mathrm{T}$ HE EXTENT and rate of digestion of herbaceous biomass by ruminants and its bioconversion to ethanol in a biorefinery is dependent on its cell wall composition and the linkages of cell wall components to each other (Vogel and Jung, 2001; Casler and Jung, 2006; Jung et al., 2012; DeMartini et al., 2013; Loqué et al., 2015). Both the amounts and types of cell wall carbohydrates, lignin, and hydroxycinnaminates are known to affect digestibility by ruminants and conversion to ethanol, including ferulate and diferulate molecules that can be esterified to arabinoxylan and covalently linked to lignin by ether and ester bonds (Sarath et al., 2008, 2011; Jung et al., 2012; Molinari et al., 2013). Previous research has demonstrated that these cell wall compounds can be genetically modified using both conventional (Casler and Jung, 1999; Sarath et al., 2008, 2011; Vogel et al., 2013) and molecular plant breeding approaches (Fu et al., 2011a, 2011b; Saathoff

Published in Crop Sci. 57:275-281 (2017).

doi: $10.2135 /$ cropsci2016.07.0625

(C) Crop Science Society of America | 5585 Guilford Rd., Madison, WI 53711 USA All rights reserved. 
et al., 2011; Baxter et al., 2015; Cass et al., 2015; Rancour et al., 2015). The relative magnitude of the effects of all of the different biomass chemical constituents on in vitro dry matter digestibility (IVDMD) or ethanol yield from biomass saccrification and fermentation (ETOH) has not previously been studied for populations of plants that produce biomass with known differences in IVDMD and $\mathrm{ETOH}$ and that also have significant differences in concentration of most biomass composition traits. Plant populations of biomass species with these known differences are very limited, and the cost of the wet laboratory work to determine the concentration of all the composition traits has previously been prohibitive.

Switchgrass (Panicum virgatum L.) is one of the primary perennial grasses being developed as a perennial grass bioenergy crop for production on marginal cropland (Schmer et al., 2008; Mitchell et al., 2012; Moore et al., 2014). In previous research, populations and half-sib families of switchgrass, which were developed by divergent selection for IVDMD for six breeding generations, produced biomass that differed significantly for both IVDMD and ETOH and also had significant differences for over 20 biomass chemical constituents (Vogel et al., 2013, 2016). In this study, our objective was to determine which of the compounds, whose relative concentrations were genetically altered in these switchgrass populations and families, had the greatest effects on the resulting differences in IVDMD and ETOH by using multiple regression analyses. This research was made feasible by development of near-infrared reflectance spectra (NIRS) calibrations for over 25 switchgrass biomass composition traits (Table 1), which enabled the concentration of these traits to be accurately predicted at a fraction of the wet laboratory cost, as measured in both money and time (Vogel et al., 2011).

\section{MATERIALS AND METHODS}

The plant materials, field trial and sample collection work, and the laboratory procedures used in this study have been reported previously in associated research (Vogel et al., 2011, 2013). In the previous research, $2-y r$ plot means were used to determine genetic differences between populations produced in the six breeding generations and also among half-sib families produced in the last breeding generation. For simplification purposes, the populations and half-sib families produced in the six breeding generations will be referred to as "strains" in this report. In this study, the biomass composition of the biomass samples collected from all switchgrass strains were used in the regression analyses without any linkages to breeding populations or families.

In brief, a field evaluation trial was established in 2006 at the University of Nebraska's Agricultural Research and Development Center (ARDC), which is located $50 \mathrm{~km}$ west of Omaha, NE (Vogel et al., 2013). The trial included all the switchgrass strains produced by the divergent breeding for IVDMD. A plot for each strain was a single row of 10 plants spaced $1.1 \mathrm{~m}$ apart within and between rows. The experimental design was a randomized complete block with six replicates. Herbicides and hand weeding was used for weed control. In 2007 and 2008, plots were fertilized with recommended rates of $\mathrm{N}$ fertilizer $\left(115 \mathrm{~kg} \mathrm{~N} \mathrm{ha}^{-1}\right)$ in the spring and were harvested when the plants were fully flowered. Biomass samples were obtained by harvesting four or five tillers from each plant within a plot. Because heading date and flowering time were similar for all populations and families and all plots were sampled within a single day for each year, genetic variation observed among families was independent of reproductive maturity.

Harvested samples were dried in a $50^{\circ} \mathrm{C}$ oven for $48 \mathrm{~h}$ and were then ground in a two-step process to pass a $1-\mathrm{mm}$ screen. Ground samples were scanned using a Model 6500 near-infrared spectrometer (NIRSystems, Silver Springs, MD; now FOSS NIRSystems, Inc., Laurel, MD) to determine feedstock composition and conversion. A comprehensive set of switchgrass NIRS prediction equations were used to determine the concentration and composition components of the harvested biomass samples, as fully described by Vogel et al. (2011, 2013). The NIRS calibration set of samples $(n=112)$ were from regional yield trials in the US Midwest, management experiments, and breeding nurseries (Vogel et al., 2011). The NIRS calibration for ETOH was based on ethanol yield from switchgrass biomass following pretreatment and simultaneous saccharification and fermentation using commercial cellulases and Sacharomyces cerevisiae Meyen ex E.C. Hansen, which only ferments hexose sugars to ethanol (Dien et al., 2006; Vogel et al., 2011). Composition traits (Table 1), IVDMD, and ETOH concentrations were determined for 204 harvested biomass samples using the NIRS analyses.

Statistical analyses were conducted using SAS 9.4 for Windows (SAS Institute, 2012). Means and standard deviations were determined using PROC MEANS, Pearson correlations were determined using PROC CORR, and stepwise multiregression analyses were conducted using PROC REG. In the multiple regression analyses, IVDMD and ETOH were treated as dependent variables and the biomass composition traits were treated as independent variables. The BACKWARD selection option was used in the regression analyses. In the BACKWARD regression analyses, variables were deleted one by one in sequential analyses until all of the remaining independent variables were significant at least at the 0.10 level of probability, with the variable having the least contribution to the model deleted at each step (SAS Institute, 2012). In regression analyses, differences in magnitude or unit of the independent variable can affect the magnitude of the partial regression coefficients, making it difficult to use them to make comparisons among independent variables for their relative impacts on the dependent variables. Standardized partial regression coefficients can be used to make direct comparisons among independent variables for their effect on the dependent variable (Snedecor and Cochran, 1967). Standardized partial regressions coefficients were calculated using the following equation:

$$
\beta_{x i}=\left(\mathrm{SD}_{x i} / \mathrm{SD}_{y}\right) b_{x i}
$$

where $\beta_{x i}$ is standardized partial regression coefficient for the $i$ th independent composition variable $\left(x_{i}\right), \mathrm{SD}_{x i}$ is the standard deviation of the $i$ th independent $x$ variable, $\mathrm{SD}_{y}$ is the standard deviation of the $y$ dependent variable (IVDMD or ETOH), and $b_{x i}$ is the partial regression coefficient for the $x_{i}$ independent variable from the multiple regression model for the regression of the $\gamma$ dependent variable on all of the significant independent variables. The standard deviations listed in Table 1 were used to calculate the standardized partial regression coefficients. 
Table 1. Biomass composition mean and range values for 204 biomass samples harvested from switchgrass experimental strains divergently bred for high and low in vitro dry matter digestibility (IVDMD) that differed significantly for all traits.

\begin{tabular}{|c|c|c|c|c|c|}
\hline \multirow[b]{2}{*}{ Variable } & \multirow[b]{2}{*}{ Abbreviation } & \multirow[b]{2}{*}{ Mean } & \multirow[b]{2}{*}{ SD } & \multicolumn{2}{|c|}{ Range } \\
\hline & & & & Minimum & Maximum \\
\hline & & & & & \\
\hline Carbon & C & 435.4 & 3.0 & 428.0 & 443.0 \\
\hline Nitrogen & $\mathrm{N}$ & 14.6 & 1.89 & 11.1 & 18.8 \\
\hline Extracted fat & EE & 12.1 & 1.7 & 8.3 & 16.0 \\
\hline Minerals (total ash) & ash & 88.2 & 6.4 & 67.8 & 102.7 \\
\hline Klason lignin & $\mathrm{KL}$ & 166.8 & 18.7 & 121.2 & 211.1 \\
\hline Uronic acids† & UA & 17.3 & 0.6 & 15.7 & 19.1 \\
\hline Rhamnose† & $\mathrm{RHA}$ & 1.01 & 0.21 & 0.54 & 1.40 \\
\hline Fucose† & FUC & 0.12 & 0.03 & 0.03 & 0.19 \\
\hline Arabinose $†$ & ARA & 30.7 & 1.7 & 26.7 & 34.4 \\
\hline Xylose† & $X Y L$ & 198.4 & 4.8 & 182.3 & 212.0 \\
\hline Mannose† & MAN & 6.2 & 0.6 & 4.8 & 8.0 \\
\hline Galactose $†$ & GAL & 8.2 & 0.7 & 6.1 & 10.0 \\
\hline Glucose† & GLC & 285.1 & 6.4 & 267.2 & 301.4 \\
\hline$p$-Coumarate esters & PCA & 5.86 & 0.62 & 4.27 & 7.59 \\
\hline Esterified ferulates & FEST & 1.62 & 0.17 & 0.92 & 2.06 \\
\hline Etherified ferulates & FETH & 0.45 & 0.16 & 0.05 & 0.91 \\
\hline Sucrose & SUC & 18.7 & 2.9 & 11.7 & 27.8 \\
\hline Soluble glucose & GLCS & 4.3 & 1.5 & 1.4 & 8.7 \\
\hline Fructose & FRU & 3.0 & 1.1 & 0.0 & 6.6 \\
\hline Starch & STA & 4.0 & 1.8 & 0 & 8.8 \\
\hline Ethanol $\mathrm{mg} \mathrm{g}^{-1}$ dry forage & $\mathrm{ETOH}$ & 86.8 & 8.0 & 68.9 & 105.0 \\
\hline In vitro dry matter digestibility & IVDMD & 635.0 & 40.1 & 551.8 & 717.7 \\
\hline
\end{tabular}

† Cell wall carbohydrates.

\section{RESULTS AND DISCUSSION}

There was a large range in the concentration values for all of the biomass composition traits among the switchgrass biomass samples that were used in this study (Table 1). The abbreviations given for the traits in Table 1 are used in the following discussion and tables for brevity purposes. As reported in the previous study (Vogel et al., 2013), there were significant differences among populations and half-sib family means or strains, based on the 12 samples that had been harvested from the six replicates of each family or population for the 2-yr period, except for total C, cell wall concentration (CWC), soluble glucose (GLCS), and etherified ferulates (FETH). There were significant differences among strains for both ETOH and IVDMD. The range in composition values listed by trait in Table 1 represents the variations among strains that were significant for almost all traits plus the variation among replicates within strains over two harvest years and are about fourfold the standard deviation for the trait. The large range in the biomass composition traits and for IVDMD and ETOH, combined with the relatively uniform stage of reproductive maturity for all samples, supports the validity of using this population of samples to determine the relative effects of the biomass composition traits on IVDMD and ETOH. The relatively uniform stage of reproductive maturity validates inferences regarding correlative and potentially causative changes due to selection, as opposed to changes associated with variation in stage of maturity or heading date.
Pearson correlations of ETOH with the independent variables were significant $(P \leq 0.01)$ for all composition traits except for mannose (MAN), esterified ferulates (FEST), and FETH (Table 2). For IVDMD, Pearson correlations were significant for all variables except for FETH. Klason lignin

Table 2. Pearson correlations ( $r$ ) between switchgrass biomass composition variables and ethanol yield (ETOH) and in vitro dry matter digestibility (IVDMD).

\begin{tabular}{|c|c|c|}
\hline \multirow[b]{2}{*}{ Trait } & \multicolumn{2}{|c|}{$r$} \\
\hline & ETOH & IVDMD \\
\hline $\bar{N}$ & $0.83^{\star \star}$ & $0.89^{\star *}$ \\
\hline C & $0.49^{\star \star}$ & $0.41^{\star *}$ \\
\hline Glucose & $-0.43^{\star \star}$ & $-0.45^{\star \star}$ \\
\hline Xylose & $-0.38^{\star \star}$ & $-0.48^{\star \star}$ \\
\hline Mannose & 0.13 & $0.25^{\star \star}$ \\
\hline Klason lignin & $-0.72^{\star \star}$ & $-0.66^{\star \star}$ \\
\hline Extracted fat & $-0.72^{\star \star}$ & $-0.67^{\star \star}$ \\
\hline Rhamnose & $0.81^{\star \star}$ & $0.84^{\star \star}$ \\
\hline Fucose & $-0.62^{\star \star}$ & $-0.69^{\star *}$ \\
\hline Arabinose & $0.90^{\star *}$ & $0.89^{* *}$ \\
\hline Uronic acids & $0.79^{\star \star}$ & $0.85^{\star \star}$ \\
\hline Galactose & $0.86^{\star \star}$ & $0.86^{\star \star}$ \\
\hline Sucrose & $0.34^{\star \star}$ & $0.18^{\star \star}$ \\
\hline Soluble glucose & $-0.59^{\star \star}$ & $-0.65^{\star \star}$ \\
\hline Fructose & $0.27^{\star \star}$ & $0.22^{\star \star}$ \\
\hline Starch & $-0.52^{\star \star}$ & $-0.54^{\star \star}$ \\
\hline$p$-Coumarate esters & $-0.71^{\star \star}$ & $-0.72^{\star \star}$ \\
\hline Esterified ferulates & 0.11 & 0.09 \\
\hline Etherified ferulates & -0.09 & $-0.18^{\star \star}$ \\
\hline Minerals (total ash) & $-0.36^{\star \star}$ & $-0.24^{\star \star}$ \\
\hline IVDMD & $0.94^{* *}$ & \\
\hline
\end{tabular}

** Significant at the 0.01 probability level. 
(KL), glucose (GLC), xylose (XYL), extracted fat (EE), fucose (FUC), GLCS, starch (STA), p-coumarate esters (PCA), and ash were significantly negatively correlated to both ETOH and IVDMD while nitrogen $(\mathrm{N})$, carbon $(\mathrm{C})$, rhamnose (RHA), arabinose (ARA), uronic acids (UA), galactose (GAL), sucrose (SUC), and fructose (FRU) were positively correlated. It should be noted that the correlation between IVDMD and ETOH also was highly significant $(r$ $=0.94, P \leq 0.01)$. This positive relationship was predicted by Vogel and Jung (2001). Anderson et al. (2010) reported a smaller $(r=0.55, P=0.01)$ positive correlation between IVDMD and ETOH with bermudagrass [Cynodon dactylon (L.) Pers.] regrowth biomass samples. In a study in which a small number of switchgrass plants with significant genetic differences in biomass IVDMD were compared, the plants with increased biomass IVDMD also had increased ETOH yield (Sarath et al., 2011).

In the multiregression analyses for IVDMD, the composition variables KL, UA, GAL, MAN, SUC, GLCS, and FETH were eliminated, in that order, in the stepwise, backward analyses (Table 3). The final regression model was highly significant, with a coefficient of determination $\left(R^{2}\right)$ value of 0.95 (Table 3). Eleven composition variables had significant effects ( $\mathrm{P} \leq 0.05$ or smaller) on IVDMD. The significant partial regression coefficients in the model (Table 3) were used to calculate the standardized partial regression coefficients. The traits that had significant effects on switchgrass IVDMD in order of the absolute value of their standard partial regression coefficients were N, FEST, PCA, RHA, XYL, FUC, ARA, ash, EE, FRU, GLC, and STA (Table 3). As indicated by the negative sign of the standardized partial regression coefficients, PCA, RHA, XYL, FUC, ash, EE, and GLC had negative effects on IVDMD, in their order of magnitude, while the other variables had positive effects on IVDMD. Etherified ferulates were the last variable eliminated from the model with a probability level of $P<0.14$. The lack of significance for FETH may have been due to insufficient power, because FETH concentration did not vary significantly among the switchgrass strains (Vogel et al., 2013). Etherified ferulates have previously been closely associated with IVDMD in several different C3 grasses for which heading date was also maintained at a near-constant value (Casler and Jung, 1999, 2006).

In the ETOH regression analyses, the composition variables GLCS, GAL, KL, STA, FUC, MAN, GLC, and UA were eliminated, in that order, in the stepwise, backward analyses (Table 4). The final regression model, which contained 11 biomass composition variables, was highly significant with a coefficient of determination $\left(R^{2}\right)$ value of 0.96 (Table 4). The traits that had significant effects on ETOH, ranked by their absolute value, were PCA, FEST, ARA, RHA, EE, N, XYL, SUC, ash, FRU, and FETH. Traits that had negative effects on ETOH were PCA, RHA, EE, XYL, and ash, while the remaining traits had a positive effect on ETOH.

The multiregression results for both IVDMD and ETOH differ from results that would be expected from the Pearson correlation analysis, in which KL concentration was highly correlated to both IVDMD and ETOH. In the correlation analyses, FEST was not correlated to either IVDMD or ETOH. In the regression analyses, in which all the major biomass composition traits were evaluated

Table 3. Regression of switchgrass in vitro dry matter digestibility (IVDMD) on biomass composition components. Deleted variables that were not significant at the $\mathbf{0 . 1 0}$ level of probability are listed in the order that they were removed in backwardelimination stepwise regression.

\begin{tabular}{|c|c|c|c|c|c|c|c|}
\hline \multirow[b]{2}{*}{ Explanatory variable } & \multirow[b]{2}{*}{$\beta \boldsymbol{x} \dagger$} & \multicolumn{6}{|c|}{ Regression of IVDMD on biomass composition properties } \\
\hline & & $\begin{array}{l}\text { Intercept or } \\
\text { variable } b_{x}\end{array}$ & Standard Error & Type II SS $\ddagger$ & $F$ value & Deleted variables & $R^{2}$ for mode \\
\hline & & $\mathrm{mg} \mathrm{g}^{-1}$ & & & & & \\
\hline Intercept & & 851.51 & 62.64 & 15944.00 & $184.76^{\star \star \star}$ & & $0.95^{\star \star \star}$ \\
\hline $\mathrm{N}$ & 0.50 & 10.54 & 1.08 & 8195.45 & $94.96^{\star \star \star}$ & Klason lignin & \\
\hline Extracted fat & -0.07 & -1.68 & 0.69 & 509.12 & $5.90^{*}$ & Uronic acids & \\
\hline Minerals (total ash) & -0.09 & -0.56 & 0.15 & 1280.71 & $14.84^{\star \star \star}$ & Galactose & \\
\hline Rhamnose & -0.21 & -39.77 & 10.16 & 1320.81 & $15.30^{\star \star \star}$ & Mannose & \\
\hline Fucose & -0.14 & -188.12 & 45.44 & 1479.17 & $17.14^{\star \star \star}$ & Sucrose & \\
\hline Arabinose & 0.13 & 2.98 & 1.41 & 385.97 & $4.47^{\star}$ & Soluble glucose & \\
\hline Xylose & -0.15 & -1.22 & 0.25 & 2008.40 & $23.27^{\star \star \star}$ & Etherified ferulates§ & \\
\hline Glucose & -0.06 & -0.40 & 0.18 & 417.93 & $4.84^{\star}$ & & \\
\hline Fructose & 0.07 & 2.72 & 0.65 & 1497.31 & $17.35^{\star \star \star}$ & & \\
\hline$p$-Coumarate esters & -0.42 & -26.99 & 4.06 & 3820.71 & $44.27^{\star \star \star}$ & & \\
\hline Esterified ferulates & 0.44 & 104.68 & 8.44 & 13281.00 & $153.90^{\star \star \star \star}$ & & \\
\hline Starch & 0.09 & 2.04 & 0.59 & 1043.00 & $12.09^{\star \star \star}$ & & \\
\hline
\end{tabular}

* Significant at the 0.05 probability level; ${ }^{\star \star}$ significant at the 0.01 probability level; ${ }^{\star \star \star}$ significant at the 0.001 probability level.

$\dagger \beta x$ is the standardized partial regression coefficient for the explanatory variable.

‡SS, sum of squares for the variable in the regression analyses.

$\S$ Statistically significant at the 0.15 level of probability. 
Table 4. Regression of switchgrass ethanol yield (ETOH) produced in a laboratory saccharification and fermentation process on biomass composition components. All variables left in models were significant at least at the 0.1 level of probability. Deleted variables that were not significant at the 0.10 level of probability are listed in the order that they were removed in backward-elimination stepwise regression.

\begin{tabular}{|c|c|c|c|c|c|c|c|}
\hline \multirow[b]{2}{*}{ Explanatory variable } & \multirow[b]{2}{*}{$\beta x \dagger$} & \multicolumn{6}{|c|}{ Regression of ETOH on biomass composition properties } \\
\hline & & $\begin{array}{l}\text { Intercept or } \\
\text { variable } b_{x}\end{array}$ & Standard error & Type II SS & $F$ Value & Deleted variables & $R^{2}$ for model \\
\hline & & $\mathrm{mg} \mathrm{g}^{-1}$ & & & & & \\
\hline Intercept & & 113.89 & 11.12 & 262.16 & $104.85^{\star \star *}$ & & $0.96^{\star \star \star}$ \\
\hline $\mathrm{N}$ & 0.16 & 0.69 & 0.17 & 39.59 & $15.83^{\star \star \star}$ & Soluble glucose & \\
\hline Extracted fat & -0.18 & -0.84 & 0.11 & 144.26 & $57.70^{\star \star *}$ & Galactose & \\
\hline Minerals (total ash) & -0.12 & -0.15 & 0.03 & 62.86 & $25.14^{\star \star \star}$ & Klason lignin & \\
\hline Rhamnose & -0.25 & -9.39 & 1.91 & 60.29 & $24.11^{\star \star \star}$ & Starch & \\
\hline Arabinose & 0.31 & 1.48 & 0.22 & 109.24 & $43.69^{\star \star \star}$ & Fucose & \\
\hline Xylose & -0.13 & -0.22 & 0.04 & 67.39 & $26.95^{\star \star \star}$ & Mannose & \\
\hline Sucrose & 0.12 & 0.33 & 0.08 & 47.92 & $9.16^{\star \star \star}$ & Glucose & \\
\hline Fructose & 0.08 & 0.56 & 0.13 & 42.70 & $17.08^{\star \star *}$ & Uronic acids & \\
\hline$p$-Coumarate esters & -0.58 & -7.44 & 0.71 & 277.80 & $111.11^{\star \star \star}$ & & \\
\hline Esterified ferulates & 0.38 & 17.95 & 1.62 & 306.99 & $122.78^{\star \star \star *}$ & & \\
\hline Etherified ferulates & 0.03 & 1.73 & 0.81 & 11.29 & $4.51^{\star}$ & & \\
\hline
\end{tabular}

* Significant at the 0.05 probability level; ${ }^{\star \star}$ significant at the 0.01 probability level; ${ }^{* \star *}$ significant at the 0.001 probability level.

$\dagger \beta x$ is the standardized partial regression coefficient for the explanatory variable.

$\ddagger$ SS, sum of squares for the variable in the regression analyses.

together, KL was not a significant variable, while FEST was a highly significant composition trait affecting both IVDMD and ETOH. Pearson correlations quantify the degree to which the biomass composition compounds covaried positively or negatively but do not show cause and effect relationships. Conversely, the standardized partial regression coefficients show potential cause-and-effect relationships that are independent of all other potential explanatory variables in the model (Bhatt, 1973).

The biomass composition factors that had the largest impact in the regression analyses on both IVDMD and ETOH were FEST, PCA, several specific cell wall sugars, $\mathrm{N}$, and EE. A possible mechanism for the impact of EE is unknown. The significant positive effect of $\mathrm{N}$ is probably due to the need of rumen microorganisms and yeast for $\mathrm{N}$ to produce the enzymes needed for digestion of the biomass cell wall complex carbohydrates. Anderson et al. (2010) also reported a positive effect of N on IVDMD for bermudagrass biomass. Cell wall sugars directly involved in covalent linkages between the lignin and hemicellulose XYL and ARA were consistently associated with both IVDMD and ETOH. Soluble xylan oligomers have been observed to be a potent inhibitor of cellulases (Qing et al., 2010), which may explain the consistent negative effect of XYL. Conversely, plants with more ARA had consistently higher IVDMD and ETOH, suggesting that more ARA sidechains creates a cell wall matrix that is more readily fermented. It has been observed that increased ARA:XYL negatively affects cellulose crystallinity (Wang et al., 2016). In their comprehensive recent review, Wang et al. (2016) indicate that replacement of XYL by ARA increased biomass saccrification, which supports our results. The results of this study indicate that, for switchgrass biomass, the total amount of lignin is not the primary factor affecting digestion by ruminants or conversion to ethanol in a biorefinery. The multiple regression analyses results indicate that the primary factors are the compounds that comprise the lignin and cell wall carbohydrate linkages that inhibit the breakdown of plant cell walls.

Much of the research on using molecular engineering to modify plant biomass for use as feedstock in cellulosic biorefineries or forage has been focused on reducing lignin concentration (Fu et al., 2011a, 2011b; Saathoff et al., 2011; Baxter et al., 2015; Cass et al., 2015), although some other traits have also been targeted (Rancour et al., 2015). Biomass from some of the genetically modified plants with reduced lignin concentration has exhibited improved ethanol yields in saccharification and fermentation tests (Fu et al., 2011a, 2011b; Baxter et al., 2015). The results of this study would indicate that reduction in lignin concentration reduces the number of lignin-cell wall carbohydrate bonds that inhibit digestion of forage by ruminants and bioconversion of biomass to ethanol. Previous research has indicated that digestion of pretreated biomass by cellulases is limited by access to cell wall cellulose (Jeoh et al., 2007), which supports the results of this study.

The number of genes believed to affect cell wall development and composition of switchgrass has been estimated to be more than 1600 (Chen et al., 2016), which indicates that multiple factors affect switchgrass biomass structure and composition. The results of this study demonstrate that biomass composition factors other than lignin concentration per se have a significant impact on the conversion of biomass by ruminants or conversion 
to ethanol in biorefineries. These results also demonstrate that the IVDMD test used in the breeding work to develop the divergent switchgrass populations served as a biological selection index that enabled genetic changes to be made for multiple composition traits controlled by an array of genes. The IVDMD assay requires access to rumen fluid that may not be available to some researchers; however, highly predictive NIRS calibrations for IVDMD have been developed (Vogel et al., 2011). These calibrations are publicly available (Vogel et al., 2011) and are robust (Casler and Vogel, 2014). Recently, Solomon et al. (2016) reported that gut fungi isolated from several different mammalian herbivores produce a large array of biomass-degrading enzymes, and they suggested that these gut fungi should be considered for use in the biofuels industry. If these isolated ruminant gut fungi and other organisms are used in the conversion of biomass to liquid fuels, they also could be used as biological selection agents to breed improved biomass crops. The filter bag procedure used for IVDMD analyses (Vogel et al., 1999) could be modified for using these fungi, and the results could be used to develop specific NIRS prediction equations that would enable a large number of samples to be rapidly analyzed. Although this research was conducted on switchgrass, its results are applicable to other grasses based on the comprehensive review by Jung et al. (2012). The divergent switchgrass populations used in this study have been released and are publically available as germplasms for use by other researchers (Vogel et al., 2016).

\section{Conflict of Interest}

The authors declare that there is no conflict of interest.

\section{References}

Anderson, W.F., B.S. Dien, H.J.G. Jung, K.P. Vogel, and P.J. Weimer. 2010. Effects of forage quality and cell wall constituents of bermudagrass on biochemical conversion to ethanol. BioEnergy Res. 3:225-237. doi:10.1007/s12155-009-9063-9

Baxter, H.L., C.R. Poovaiah, K.L. Yee, M. Mazarei, M. Rodriguez, Jr., O.A. Thompson et al. 2015. Field evaluation of transgenic switchgrass plants overexpressing PvMYB4 for reduced biomass recalcitrance. BioEnergy Res. 8:910-921. doi:10.1007/s12155-014-9570-1

Bhatt, G.M. 1973. Significance of path coefficient analysis in determining the nature of character association. Euphytica 22:338-343. doi:10.1007/BF00022643

Casler, M.D., and H.-J.G. Jung. 2006. Relationship of fibre, lignin, and phenolics to in vitro fibre digestibility in three perennial grasses. Anim. Feed Sci. Technol. 125:151-161. doi:10.1016/j. anifeedsci.2005.05.015

Casler, M.D., and H.-J.G. Jung. 1999. Selection and evaluation of smooth bromegrass clones with divergent lignin and etherified ferulic acid concentration. Crop Sci. 39:1866-1873. doi:10.2135/cropsci1999.3961866x

Casler, M.D., and K.P. Vogel. 2014. Selection for biomass yield in upland, lowland, and hybrid switchgrass. Crop Sci. 54:626636. doi:10.2135/cropsci2013.04.0239
Cass, C.L., A. Peraldi, P.F. Dowd, Y. Mottiar, N. Santoro, S.D. Karlen et al. 2015. Effects of phenylalanine ammonia lyase (PAL) knockdown on cell wall composition, biomass digestibility, and biotic and abiotic stress responses in Brachypodium. J. Exp. Bot. 66:4317-4335. doi:10.1093/jxb/erv269

Chen, X., M. Qin, X. Rao, Y. Tang, Y. Wang, G. Li et al. 2016. Genome-scale identification of cell-wall related genes in switchgrass through comparative genomics and computational analyses of transcription data. BioEnergy Res. 9:172180. doi:10.1007/s12155-015-9674-2

DeMartini, J.D., S. Pattathil, J.S. Miller, H. Li, M.G. Hahn, and C.E. Wyman. 2013. Investigating plant cell wall components that affect biomass recalcitrance in popular and switchgrass. Energy Environ. Sci. 6:898-909. doi:10.1039/c3ee23801f

Dien, B.S., H.G. Jung, K.P. Vogel, M.D. Casler, J.F.S. Lamb, P.J. Weimer et al. 2006. Chemical composition and response to dilute-acid pretreatment and enzymatic saccharification of alfalfa, reed canarygrass, and switchgrass. Biomass Bioenergy 30:880-891. doi:10.1016/j.biombioe.2006.02.004

Fu, C., J.R. Mielenz, X. Xiao, Y. Ge, C.Y. Hamilton, M. Rodriguez, Jr. et al. 2011a. Genetic manipulation of lignin reduces recalcitrance and improves ethanol production from switchgrass. Proc. Natl. Acad. Sci. USA 108:3803-3808. doi:10.1073/pnas.1100310108

Fu, C., X. Xiao, Y. Xi, Y. Ge, F. Chen, J. Bouton et al. 2011 b. Downregulation of cinnamyl alcohol dehydrogenase (CAD) leads to improved saccrification efficiency in switchgrass. BioEnergy Res. 4:153-164. doi:10.1007/s12155-010-9109-z

Jeoh, T., C.I. Ishizawa, M.F. Davis, M.E. Himmel, W.S. Adney, and D.K. Johnson. 2007. Cellulase digestibility of pretreated biomass is limited by cellulose accessibility. Biotechnol. Bioeng. 98:112-122. doi:10.1002/bit.21408

Jung, H.J.G., D.A. Samac, and G. Sarath. 2012. Modifying crops to increase cell wall digestibility. Plant Sci. 185-186:65-77. doi:10.1016/j.plantsci.2011.10.014

Loqué, D., H. Scheller, and M. Pauley. 2015. Engineering of plant cell walls for enhanced biofuel production. Curr. Opin. Plant Biol. 25:151-161. doi:10.1016/j.pbi.2015.05.018

Mitchell, R., K.P. Vogel, and D.R. Uden. 2012. The feasibility of switchgrass for biofuel production. Biofuels 3:47-59. doi:10.4155/bfs.11.153

Molinari, H.B.C., T.K. Peliny, J. Freeman, P.R. Shewry, and R.A.C. Mitchell. 2013. Grass cell wall feruloylation: Distribution of bound ferulate and candidate gene expression in Brachypodium distachyon. Front. Plant Sci. 4:50. doi:10.3389/ fpls.2013.00050

Moore, K.J., S. Birrell, R.C. Brown, M.D. Casler, J.E. Euken, H.M. Hanna et al. 2014. Midwest vision for sustainable fuel production. Biofuels 5:687-702. doi:10.1080/17597269.2015.1015312

Qing, Q.B., C.E. Yang, and C.E. Wyman. 2010. Xylooligomers are strong inhibitors of cellulose hydrolysis by enzymes. Bioresour. Technol. 101:9624-9630. doi:10.1016/j.biortech.2010.06.137

Rancour, D.M., R.D. Hatfield, J.M. Marita, N.A. Rohr, and R.J. Schmitz. 2015. Cell wall composition and digestibility alterations in Brachypodium distachyon achieved through reduced expression of UDP-arabinoyranose mutase. Front. Plant Sci. 6:446. doi:10.3389/fpls.2015.00446

Saathoff, A.J., G. Sarath, E.K. Chow, B.S. Dien, and C.M. Tobias. 2011. Downregulation of cinnamyl-alcohol dehydrogenase in switchgrass by RNA silencing results in enhanced glucose release after cellulase treatments. PLoS One 6(1):e16416. doi:10.1371/journal.pone.0016416 
Sarath, G., D. Akin, R.B. Mitchell, and K.P. Vogel. 2008. Cell wall composition and accessibility to enzymes is differentially altered in divergently bred switchgrass (Panicum virgatum. L.) genotypes. Appl. Biochem. Biotechnol. 150:1-14. doi:10.1007/s12010-008-8168-5

Sarath, G., B. Dien, A. Saathoff, K.P. Vogel, R.B. Mitchell, and H. Chen. 2011. Ethanol yields and cell wall properties in divergently bred switchgrass genotypes. Bioresour. Technol. 102:9579-9585. doi:10.1016/j.biortech.2011.07.086

SAS Institute. 2012. The SAS system for Windows. Release 9.4. SAS Inst., Cary, NC.

Schmer, M.R., K.P. Vogel, R.B. Mitchell, and R.K. Perrin. 2008. Net energy of cellulosic ethanol from switchgrass. Proc. Natl. Acad. Sci. USA 105:464-469. doi:10.1073/pnas.0704767105

Solomon, K.V., C.H. Haijema, J.K. Henske, S.P. Gilmore, D. Borges-Rivera, A. Lipzen et al. 2016. Early-branching gut fungi possess a large, comprehensive array of biomass-degrading enzymes. Science 351:1192-1195. doi:10.1126/science. aad1431

Snedecor, G.W., and W.G. Cochran. 1967. Statistical methods. 6th ed. Iowa State Univ. Press. Ames, IA.

Vogel, K.P., B.S. Dien, H.J. Jung, M.D. Casler, S. Masterson, and R.B. Mitchell. 2011. Quantifying actual and theoretical biomass ethanol yields for switchgrass strains using NIRS analyses. BioEnergy Res. 4:96-110. doi:10.1007/s12155-0109104-4
Vogel, K.P., and H.G. Jung. 2001. Genetic modification of herbaceous plants for feed and fuel. Crit. Rev. Plant Sci. 20:15-49. doi:10.1080/20013591099173

Vogel, K.P., R.B. Mitchell, and G. Sarath. 2016. Registration of 'NE Trailblazer C-1', 'NE Trailblazer C0', 'NE Trailblazer C2', 'NE Trailblazer C3', 'NE Trailblazer C4', and 'NE Trailblazer C5’ switchgrass germplasms. J. Plant Reg. 10:159-165. doi:10.3198/jpr2015.11.0070crg

Vogel, K.P., R.M. Mitchell, G. Sarath, H.G. Jung, B.S. Dien, and M.D. Casler. 2013. Switchgrass biomass composition altered by six generations of divergent breeding for digestibility. Crop Sci. 53:853-862. doi:10.2135/cropsci2012.09.0542

Vogel, K.P., J.F. Pedersen, S.D. Masterson, and J.J. Toy. 1999. Evaluation of a filter bag system for NDF, ADF, and IVDMD forage analysis. Crop Sci. 39:276-279. doi:10.2135/cropsci199 9.0011183X003900010042x

Wang, Y., C. Fan, H. Hu, Y. Li, D. Sun, Y. Wang, and L. Peng. 2016. Genetic modification of plant cell walls to enhance biomass yield and biofuel production in bioenergy crops. Biotechnol. Adv. 34:997-1017. doi:10.1016/j.biotechadv.2016.06.001 